\title{
Food and Feeding Habits of Sarpa salpa Salema (family: Sparidae) in the Libyan Coast of the Mediterranean Sea
}

\author{
Ashraf I. Ahmed ${ }^{1}$; Salah G. El-Etreby ${ }^{1}$; Magdy A. Alwany ${ }^{1}$ and \\ Randa A. Ali. ${ }^{2}$ \\ 1- Marine Science Department, University of Suez-Canal Ismailia, Egypt \\ 2- Omar El-moktar University, Libya
}

\section{ABSTRACT}

A total of 378 fish of Sarpa salpa were collected from eastern coast Libya 16 month period for biological study of food and feeding habits numerical method and the percentage of fish that contain low empty stomach. It was found that sea grasses is the main food of these fish that depend on it by $79.10 \%$ and following by algae with $15.10 \%$ and $4.33 \%$ crustaceans and there is no clear relationship between the lengths of these fish and the size of the food they eat.

Keywords: Food and feeding habits, Sarpa salpa, Libyan coast, Mediterranean Sea

\section{INTRODUCTION}

Studies on feeding biology of any organism depend firstly on a listing of prey organisms exploited, followed by assessment of the relative importance in diet, The diet studies based upon analysis of stomach contents is now a standard practice in fish ecology (Hynes, 1950; Pillay, 1952 and Lagler 1956).

The study of feeding preferences of fish species is important in classic ecological theory, mainly in identifying feeding composition, structure and stability of food webs (Post et al., 2000).

It is known that members of the family Sparide feed on live food (Ahmed, 1999). On the studying the feeding behavior of youngs and adults of $S$. salpa in the different areas of Mediterranean sea, Verlaque (1990) found that they have essentially herbivorous grazing ability and trophic mobility. The young fishes preferred mainly the epiphytes and filamentous algae. Some sparids, don't change their feeding habits along their life span, Hussain et al. (1987).

Some studies revealed that $S$. salpa in the various age groups feed mainly on detritus (Tomac et al., 2000).

This present work concerned with studying diet of $S$. salpa and their monthly variation diet composition and variations of diets with length that were examined by the points of assessment method and data were expressed as percentage of the total food items.

\section{MATERIAL AND METHODS}

A total of 378 specimens of $S$. salpa collected in different months, were used to study food and feeding habits of the studied species. Each fish was weighted freshly to nearest $0.01 \mathrm{gm}$ and its total length was determined in $\mathrm{cm}$ and the stomach was cut longitudinally and its contents were escaped out and transferred into a small Petri dish. Food items were sorted out and then identified as far as possible. Numerical methods were chosen for food analysis was applied to assess the volume of each food items by visual estimation. this method gives each food item point from 1-5 (e.g.0,1,2,3,4 and 5) were allotted to empty, quarter full ,half full, three quarter full 
and completely full respectively. Monthly variation in diet composition was also examined and data were expressed annually and visual estimation for volume of each food item was done in order to apply point method (Hynes, 1950; Kislalioglue \& Gibson, 1977).

Method of Hynes (1950) was adopted in the present study. The statistics measuring of food composition were drived by Godfriaux (1969).

\section{RESULTS \& DICUSSION}

\section{Annual diet composition}

Figure (1) displayed the percentage of the annual composition of $S$. salpa diet, Algae, Seagrasses crustacean, poly chaeta digested food, and sediment is the main food groups for S. salpa.

Seagrasses were the major food items constituting $79.16 \%$ of all food consumed. Algae are the second food items constituting $15.10 \%$ of all food consumed, Crustacea constituted $4.33 \%$ of all food consumed in S. salpa. Polychaeta is one of minor food with about $0.41 \%$ of all food consumed, Digested food constituted $1.07 \%$ of all food consumed and sediment represented $0.10 \%$ of all food consumed.

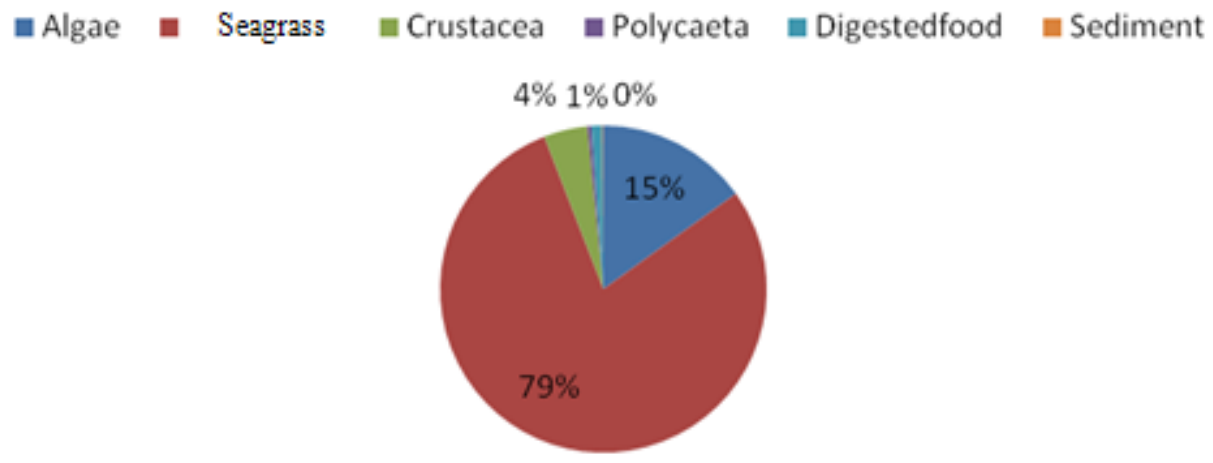

Fig. 1: Percentage of food composition of $S$. salpa.

This study is consistent with Tomac et al. (2000), who studied he feeding nutritional of $S$. salpa in the Souh Adriatic in Croatia and found that these species feed mainly on Seagrasses and Algae and crustacean also Ahmed, 1999 reported that the composition of $S$. salpa stomach contents collected off the South Sinai coasts which are volumetrically Seagrasses and Algae.

\section{Monthly variations in the diet composition:}

Monthly variations in the diet composition of $S$. salpa is illustrated in Table (1) by volume composition. Seagrasses recorded the highest value in August 2010 and February 2011 (100\%), whereas the lowest value was recorded in May (3.21\%). Algae disappeared in August 2010, January, February and March 2011, However, algae formed the largest component in December $2010(77.15 \%)$ and May 2011(34\%), while come crustaceans, Polychaeta and digested come with low rates in all months.

This agreement with Tomac et al., (2000), who reported that S. salpa was considered as that depend on the Seagrasses for food also Verlaquc (1990) studied the feeding behavior of $S$. salpa and the found that it is mainly herbivorous fish. Its dietary selectivity changed according to increase of its vertical distribution and grazing ability. In dense algal settlement, $S$. salpa behaved as highly selective herbivorous browser. When the trophic resources were overgrazed, it tend to become 
a generalist grazer, feeding upon erect alage and on Seagraasses posidonia oceanic (L) delile leaves.

Table 1: Monthly variation in diet composition of $S$. salpa.

\begin{tabular}{|l|c|c|c|c|c|c|}
\hline \multirow{2}{*}{ Months } & \multicolumn{7}{c|}{ Percentages of food items } \\
\cline { 2 - 7 } & Algae & Seagrasses & Crustacea & Polychaeta & Digested & Sediment \\
\hline May (2010) & 12 & 85.9 & 2.1 & 0 & 0 & 0 \\
\hline Jun & 3.1 & 91.3 & 0.9 & 0 & 4.6 & 0 \\
\hline Jul & 67.1 & 27.4 & 5.5 & 0 & 0 & 0 \\
\hline Aug & 0 & 100 & 0 & 0 & 0 & 0 \\
\hline Sep & 0.6 & 99 & 0.32 & 0 & 0 & 0 \\
\hline Oct & 50.8 & 44.2 & 1.4 & 0 & 3.5 & 0 \\
\hline Nov & 0.38 & 98.8 & 0 & 0 & 0.76 & 0 \\
\hline Dec & 77.15 & 15 & 0 & 6.54 & 0 & 1.7 \\
\hline Jan $(2011)$ & 0 & 96 & 0 & 0 & 3.91 & 0 \\
\hline Feb & 0 & 100 & 0 & 0 & 0 & 0 \\
\hline Mar & 0 & 96.8 & 0 & 0 & 3.1 & 0 \\
\hline Apr & 8.86 & 89 & 0 & 0 & 1.5 & 0 \\
\hline May & 34 & 62 & 3.21 & 0.91 & 0.14 & 0 \\
\hline Jun & 23.9 & 75.3 & 0.63 & 0 & 0 & 0 \\
\hline Jul & 13 & 85 & 2 & 0 & 0 & 0 \\
\hline Aug & 6.51 & 93.4 & 0 & 0 & 0 & 0 \\
\hline
\end{tabular}

\section{Food habits in relation to the length:}

Fishes were classified into nine classes from 15.1 to $42 \mathrm{~cm}$ with $3 \mathrm{~cm}$ interval, the relation between food habits and length of $S$. salpa is represented in Fig. (2). Algae were found in all length groups and the percentage increased from $10 \%$ in small fish $(15.1-18 \mathrm{~cm})$ by volume composition, reaching their highest level $(100 \%)$ in biggest fish $(39.1-42 \mathrm{~cm})$, Sea grasses disappeared in range length $(39.1-42 \mathrm{~cm})$, however crustaceans disappeared in largest size fish from length group $(18.1-21$ $\mathrm{cm})$, Polychaeta found in range $(21.1-24 \mathrm{~cm}) 0.35 \%$, then the digested food were found in small length $(15.1-18 \mathrm{~cm})$. Thus, the highest rates of food items were sea grasses and algae in most lengths.



Fig. 2: The diet composition of different length classes of S. Salpa. 


\section{Intensity of food}

The intensity of feeding was illustrated in Table (2), intensity of feeding in S.salpa clearly indicates high rate of feeding activity fishes with stomachs half full, three-quarter full and full of food constitute $59.66 \%$ of all analyzed individuals, whereas those with empty, traces of food and quarter full stomach were represented by $40.32 \%$ of total specimens. However, the intensity of food varied considerably from one month to another. The percentage of stomach full of food recorded the highest values in November (32\%).

Table 2: Monthly variations in the intensity of food in the stomach of S. Salpa.

\begin{tabular}{|l|c|c|c|c|c|c|c|}
\hline \multirow{2}{*}{ Months } & \multicolumn{7}{|c|}{ Intensity of food in the stomach } \\
\cline { 2 - 8 } & $\begin{array}{c}\text { No. } \\
\text { of fish }\end{array}$ & Empty & Trace & $\mathbf{1 / 4}$ & $\mathbf{1 / 2}$ & $\mathbf{3 / 4}$ & Full \\
\hline May 2010 & $\mathbf{2 6}$ & $\mathbf{0 . 0}$ & $\mathbf{0 . 0}$ & $\mathbf{7 . 6 9}$ & $\mathbf{2 6 . 9 2}$ & $\mathbf{3 8 . 4 6}$ & $\mathbf{2 6 . 9 2}$ \\
\hline Jun. & 25 & 4 & 8 & 32 & 32 & 20 & 4 \\
\hline Jul. & 25 & 0.0 & 32 & 16 & 28 & 16 & 8 \\
\hline Aug. & 25 & 0.0 & 8 & 12 & 24 & 36 & 20 \\
\hline Sep. & 21 & 0.0 & 14.28 & 28.75 & 23.8 & 19.04 & 14.28 \\
\hline Oct. & 23 & 0.0 & 4.34 & 26.08 & 47.8 & 21.73 & 0.0 \\
\hline Nov. & 25 & 4 & 4 & 24 & 20 & 16 & 32 \\
\hline Dec. & 24 & 0.0 & 29.1 & 25 & 16.6 & 12.5 & 16.6 \\
\hline Jan. 2011 & $\mathbf{2 5}$ & $\mathbf{4}$ & $\mathbf{2 4}$ & $\mathbf{2 0}$ & $\mathbf{1 6}$ & $\mathbf{1 6}$ & $\mathbf{2 0}$ \\
\hline Feb. & 21 & 0.0 & 23.8 & 33.33 & 19.04 & 23.8 & 0.0 \\
\hline Mar. & 25 & 0.0 & 12 & 28 & 20 & 12 & 28 \\
\hline Apr. & 25 & 4 & 28 & 24 & 24 & 12 & 8 \\
\hline May & 25 & 4 & 28 & 16 & 24 & 16 & 12 \\
\hline Jun. & 25 & 4 & 12 & 40 & 20 & 20 & 4 \\
\hline Jul. & 22 & 0.0 & 13.6 & 27.27 & 22.72 & 22.72 & 13.6 \\
\hline Aug. & 25 & 0.0 & 4 & 16 & 32 & 40 & 8 \\
\hline
\end{tabular}

Sparidae are considered as herbivorous trophic category. Food and feeding habits of different species of Sparidae have been studied by many authors (FAO, 1987 Quignard and Tomasini, 2000; Bin-abdullah, Al-turk, 2005; Ahmed.1999).

\section{REFERENCES}

Ahmed A. I. (1999). Biological and ecological studies on some Sparidae Fishes from Southern Sinai Coasts (Red Sea). Ph. D. Thesis Faculty of Sci. Suez Canal Univ. $261 \mathrm{pp}$.

Andaloro, F.; Azzurro, E.; Emanuela, F.; Edoardo, M.; Marcello, C. and (2005). Resource partitioning among early colonizing Siganus luridus and native herbivorous fish in the Mediterranean: an integrated

FAO. Fishery country profile, 1987.

FAO. Fishery country profile, (2005). http; www.fao.org

Godfriaux, BL (1969). Food of predatory demersal fish in Hauraki Gulf.1-food and feeding habits of snapper, Shrysophyrs auratus. N: Z. Mar. Reshw. Res., 25 (3): 281-292.

Hussain, N. A.; Hamza, H. A. and Saud, K. D. (1987). Some biological aspects of the fresh water population of the sharag Acanthopagrus latus (Houttuyn) in Shatt Al-Arab River, Iraq. Marina Mesopotamica. 2(1):29-40.

Hynes, H. (1950). The food of fresh water sticklebacks Gasteroteus aculeatus and Pygosteus pungitius With are view of methods used in studies of food of fishes J. Anim Ecol., 19:36-58. 
Kislalioglu, M and Gibson, RN (1977). The feeding relationship of shallow water fishes in Scottish Sea Loch J. Fish Biol., 11:257-266.

Lagler, K. (1956). Fresh water fishery biology .Wm. C. Brown Co., Dubaque, iowa. $1-421 \mathrm{pp}$.

Pillay, T (1952). Acritique of the methods of study of food of fishes. J. Zool. Soc. India, 4 (2):185-200.

Post, D.; Conners M. and Goldberg D. (2000). Prey preference by a top predator and stability of linked food chains. Ecol., 81:8-41.

Prado. P.; Tomas. F.; Alcoverro. and Tromero. J. (2007). Extensive direct measurement of posidonia oceanic consumption confirms the importance of herbivorism in temperate Sea grass meadows. Marine Ecology progress Series 340: $63-71$.

Quignard JP. and Tomasini JA. (2000). Mediterranean fish biodiversity. Biol. Mar. Medit. 3:1-66.

Tomac, M; Glavic, N and Teskeredzic Skaramuca, B (2000). Feeding and nutritional values of the Sparid fish S. salpa L. in the Southern Adriatic (Croatia) periodicum Biologorum, 102 (3): 309-312

Verlaque, M (1990). Relations entre Sarpa salpa (L.) (Teleoseen, Sparidae), Les aurtres poisons brouteures et le phytobenthos algal Mediterranean .Oceanologica Acta 13(3): 373-388.

\section{ARABIC SUMMARY}

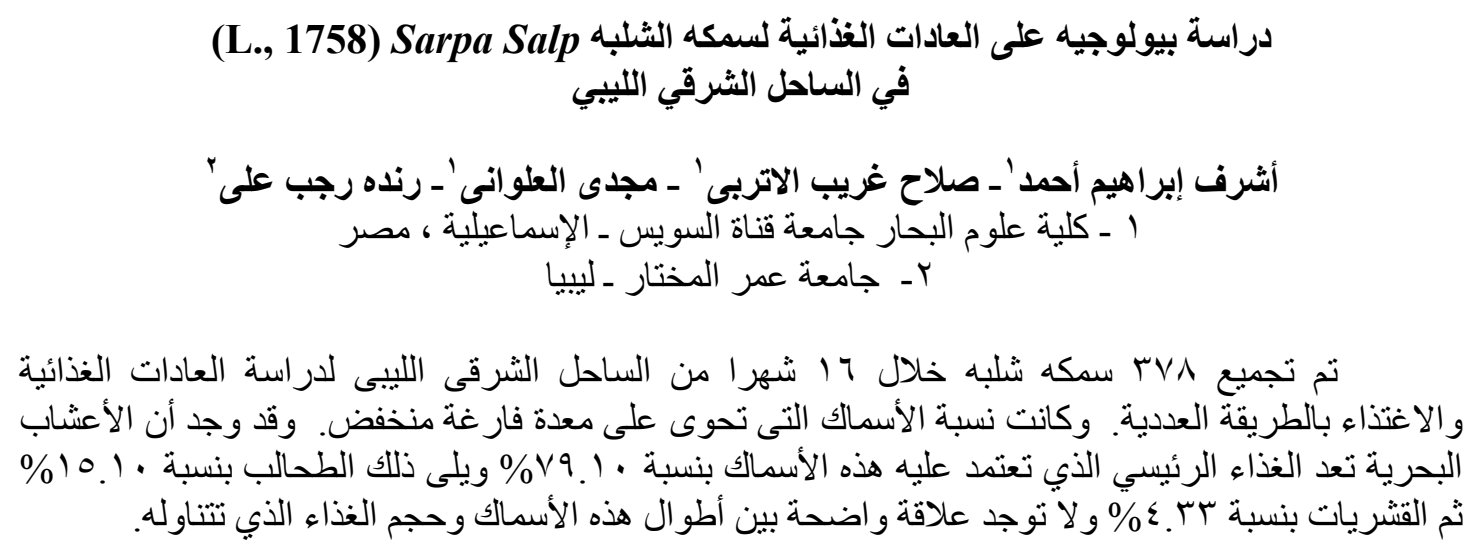

